\title{
UPAYA MENINGKATKAN HASIL BELAJAR MATEMATIKA MELALUI METODE KOOPERATIF TIPE TEAM ACCELARATED INTRUCTION (TAI)
}

\author{
Ulyati \\ SMK YASPIH RAJEG
}

\begin{tabular}{l} 
INFO ARTICLES \\
\hline Article History: \\
Received: 3 Februari 2018 \\
Revised: 17 Februari 2018 \\
Approved: 24 Februari 2018 \\
Publish Online: 2 Maret 2018 \\
\hline
\end{tabular}

Key Words:

Kooperative method learning, Team Type Accelarated Intruction (TAI), a method of Learning


ShareAlike 4.0 International License.

\begin{abstract}
This research was conducted after researchers having a problem in teaching mathematics at 10 grade CMS YASPIH RAJEG, kecamatan Rajeg, district of Tangerang. Based on that problem, researchers try to solve those problems by using cooperative learning methode to enhancement student's mathematics learning achievement. On the classroom action research, subjects are the students of class 10 AP SMK YASPIH RAJEG Rajeg subdistrict of Tangerang Regency consisting of 34 students. This research was conducted at academic years 2012/2013 from January until February 2013. The research results showed that these Class Actions that used cooperative learning methods in cycle I, II and III enhancement learning results. It can be showed from evaluation and observation in cycles I, II dan III, there are some improvements in cycle 1, average completeness only 62 and completeteness level $14.71 \%$ (5 students), in cycle II, it increase to 66.17 with completeteness level 52.96\% ( 18 students), in cycles III it become 80.13 with completeteness level 91.19\% (31 students). It showed that cooperative learning methode can improve student's learning achievement in mathematics at tenth grade in SMK YASPIH RAJEG.
\end{abstract}

Abstrak: Penelitian ini dilakukan atas dasar peneliti mengalami masalah dalam mengajar matematika khususnya dikelas 10 SMK YASPIH RAJEG, kecamatanRajeg, kabupaten Tangerang. Beranjak dari permasalahan itu, peneliti mencoba memecahkan masalah tersebut dengan menggunakan metode pembelajaran kooperatif dalam meningkatkan hasil belajar matematika siswa. Pada Penelitian Tindakan Kelas ini yang menjadi subjek penelitian adalah siswa kelas 10 AP SMK YASPIH RAJEG kecamatan Rajeg kabupaten Tangerang yang terdiri dari 34 siswa. Penelitian ini dilaksanakan pada tahun ajaran 2012/2013 yaitu dari bulan Januari sampai bulan Februari 2013. Hasil Penelitian Tindakan Kelas ini menunjukan bahwa penggunaan metode pembelajaran kooperatif pada siklus I, II dan III terjadi peningkatan hasil belajar yang cukup memuaskan. Hal ini dapat dilihat dariobservasi maupun evaluasi dari siklus I, II dan III terdapat perubahan pada hasil evaluasi yaitu pencapaian rata - rata kelas pada siklus I hanya 62 dengan tingkat ketuntasan 14,71\% (5 siswa) mengalami peningkatan pada siklus II menjadi 66,17 dengan tingkat ketuntasan 52,96\% (18 siswa) pada siklus ke III menjadi 80,13 dengan tingkat ketuntasan 91,19\% (31 siswa). Hal ini menunjukan bahwa, metode pembelajaran kooperatif cukup efektif dalam meningkat kanhasil belajar siswa khususnya matapelajaran matematika siswa kelas 10 SMK YASPIH RAJEG.

\footnotetext{
Correspondence Address: Jl. KH. Moh. Dahlan, Tanjakan, Mauk, Kedung Dalem, Tangerang, Banten 15540; e-mail: ulyati84@gmail.com

How to Cite (APA $6^{\text {th }}$ Style): Ulyati. (2018). Upaya Meningkatkan Hasil Belajar Matematika melalui Metode Kooperatif Tipe Team Accelarated Intruction (Tai) di Kelas 10 AP SMK YASPIH RAJEG Tangerang. JKPM (Jurnal Kajian Pendidikan Matematika), Vol 3(2), 165-176.

Copyright: Ulyati, (2018)

Competing Interests Disclosures: The authors declare that they have no significant competing financial, professional or personal interests that might have influenced the performance or presentation of the work described in this manuscript.
} 


\section{PENDAHULUAN}

Indonesia merupakan salah satu negara yang sedang membangun. Dengan pembangunan, Indonesia dapat sejajar dengan bangsa - bangsa yang sudah maju. Sedangkan untuk melakukan suatu pembangunan sangatlah diperlukan Sumber Daya Manusia (SDM) yang cerdas dan terampil di bidangnya masing - masing. Kecerdasan dan keterampilan tersebut dapat dikembangkan dengan adanya pendidikan.

Hasbullah (2005) mengatakan "Pendidikan adalah usaha sadar dan terencana untuk mewujudkan suasana belajar dan proses pembelajaran agar peserta didik secara aktif mengembangkan potensi dirinya untuk memiliki kekuatan spiritual keagamaan, pengendalian diri, kepribadian, kecerdasan, akhlak mulia, serta keterampilan yang diperlukan dirinya dan masyarakat, bangsa dan Negara”. Pendidikan dikatakan berhasil jika tercapai peningkatan kualitas pendidikan. Peningkatan kualitas pendidikan dapat dilihat dari meningkatnya hasil belajar siswa. Hasil belajar siswa dapat meningkat apabila siswa dapat berhasil dalam belajar. Usaha dan keberhasilan belajar dipengaruhi oleh banyak faktor. Sukmadinata (2004) menyatakan bahwa faktor-faktor yang mempengaruhi usaha dan keberhasilan belajar dapat bersumber pada diri siswa atau lingkungan siswa. Faktor yang ada pada diri individu menyangkut, Antara lain : a) Aspek jasmaniah yang dapat dibedakan menjadi dua macam yaitu keadaan jasmani pada umumnya dan fungsi alat-alat tubuh serta fungsi panca indera; b) Aspek psikis, yang meliputi kondisi kesehatan psikis, kemampuan-kemampuan intelektual, sosial, psikomotor, kondisi afektif dari individu. Kondisi afektif berupa motivasi untuk belajar. Belajar perlu didukung oleh motivasi yang kuat dan konstan. Motivasi yang lemah dan tidak konstan akan menyebabkan kurangnya usaha belajar, yang pada akhirnya akan berpengaruh terhadap hasil belajar.

Menurut Karim (2017) Hasil belajar merupakan suatu proses dari seseorang yang berusaha untuk memperoleh suatu bentuk perubahan relatif menetap. Peningkatan kualitas pendidikan dapat dilihat dari meningkatnya hasil belajar atau prestasi belajar yang diperoleh siswa. Salah satu hal yang dapat meningkatkan hasil atau prestasi belajar tersebut adalah dengan meningkatkan motivasi belajar. Motivasi merupakan daya penggerak bagi seseorang untuk menjadi aktif. Seseorang menjadi aktif pada saat-saat tertentu, terutama bila kebutuhan dirasakan atau mendesak. Dampak motivasi dalam proses pembelajaran yang ada di kelas dapat berupa serangkaian usaha untuk menyediakan kondisi-kondisi tertentu, sehingga siswa mau dan bertindak untuk melakukan sesuatu guna mencapai tujuan pembelajaran.

Model pembelajaran kooperatif merupakan model pembelajaran yang memungkinkan siswa belajar secara aktif dan partisipatif. Model pembelajaran ini memaksimalkan kegiatan belajar dengan cara mengelompokkan siswa dalam kelompok-kelompok kecil dan saling belajar bersama. Berbagai macam teknik dalam pembelajaran kooperatif diantaranya yaitu teknik Team Accelerated Instruction (TAI). Teknik ini mengkombinasikan keunggulan pembelajaran kooperatif dan pembelajaran individual. Tipe ini dirancang untuk mengatasi kesulitan belajar siswa secara individual. Oleh karena itu kegiatan pembelajarannya lebih banyak digunakan untuk pemecahan masalah, ciri khas pada tipe TAI ini adalah setiap siswa secara individual belajar materi pembelajaran yang sudah dipersiapkan oleh guru. Hasil belajar individual dibawa ke kelompok-kelompok untuk didiskusikan dan saling dibahas oleh anggota kelompok, dan semua anggota kelompok bertanggung jawab atas keseluruhan jawaban sebagai tanggung jawab bersama. 
Pembelajaran yang dilakukan di kelas akan berlangsung secara efektif jika guru dapat memilih metode yang sesuai dengan keadaan yang ada dalam kelas tersebut. Setiap guru akan menggunakan metode yang berbeda-beda satu sama lain. Pembelajaran yang dilakukan dengan melibatkan aktivitas siswa akan lebih diminati oleh siswa daripada pembelajaran yang menjadikan siswa pasif. Pembelajaran konvensional yang ada saat ini merupakan pembelajaran yang menuntut keaktifan guru dalam menyampaikan pembelajaran dan menjadikan siswa pasif. Hal tersebut membuat siswa cenderung pasif dan tidak terlalu berminat terhadap pembelajaran. Tingginya intensitas penggunaan metode ceramah yang dilakukan oleh guru menjadikan siswa tidak melakukan banyak aktivitas, sehingga guru mengalami kesulitan dalam membangkitkan motivasi siswa terhadap mata pelajaran yang diajarkan, terutama untuk mata pelajaran yang didalamnya memerlukan banyak proses menghitung, contohnya seperti pada mata pelajaran Akuntansi. Rendahnya motivasi terhadap pembelajaran akan mengakibatkan siswa tidak dapat memahami materi pelajaran dengan baik. Hal ini juga akan berpengaruh terhadap prestasi belajar siswa.

Pembelajaran yang dapat meningkatkan motivasi siswa selama proses pembelajaran adalah metode yang menggunakan pendekatan pembelajaran aktif, diantaranya adalah Metode Pembelajaran Kooperatif. Metode Pembelajaran Kooperatif tidak hanya membelajarkan kecakapan akademik saja, namun juga keterampilan sosial. Penggunaan berbagai teknik dalam metode pembelajaran kooperatif, diantaranya Teknik Pembelajaran Team Accelerated Instruction (TAI), dapat menjadikan siswa memusatkan perhatian kepada pembelajaran, sehingga siswa akan semakin termotivasi dan pemahaman siswa terhadap materi pembelajaran dapat ditingkatkan, sekaligus juga membelajarkan keterampilan sosial. Hal tersebut tampak dari adanya kerja sama antar siswa dalam Teknik Pembelajaran Team Accelerated Instruction (TAI) sebagai upaya untuk memahami konsep dalam materi pelajaran. Kerja sama tersebut akan melatih keterampilan siswa dalam hal bersosialisasi dengan teman sebaya dan juga akan berpengaruh terhadap meningkatnya prestasi belajar siswa.

Perkembangan ilmu pengetahuan dan teknologi memacu pengelola pendidikan untuk melakukan usaha guna meningkatkan mutu pendidikan. Ketika pendidikan ingin dikatakan bermutu atau maju prestasinya dapat dilihat secara objektif dan jelas.Basis pendidikan yang mengarah pada perkembangan teknologi salah satunya adalah matematika. Jatuh bangunnya suatu negara dewasa ini bergantung dari kemajuan di bidang matematika. Karena pentingnya hal tersebut maka banyak negara yang telah maju, menjadikan matematika sebagai suatu basis dalam pembangunan negaranya. Namun apabila melihat kondisi pendidikan di Indonesia dari dahulu sampai pada saat ini masih sangat memprihatinkan, hal ini dapat dilihat dari rendahnya prestasi belajar matematika pada setiap jenjang pendidikan.

Dalam upaya meningkatkan prestasi siswa terhadap matematika sangat dibutuhkan trik atau metode yang harus dikuasai dan dilakukan oleh setiap pendidik, khususnya pendidik pelajaran matematika. Hal ini perlu dilakukan karena sebagian besar siswa menganggap bahwa matematika adalah suatu pelajaran yang sulit untuk dipahami dan membosankan sehingga dapat menyebabkan banyak sekali siswa tidak menyukai pelajaran matematika pada akhirnya dapat menjadi salah satu penyebab rendahnya prestasi belajar siswa. Serta hal yang banyak dapat menyebabkan siswa tidak menyukai pelajaran matematika adalah penyampaian guru yang cenderung bersifat monoton, hampir tanpa variasi kreatif.

Pembelajaran kooperatif atau yang sering disebut dengan belajar secara berkelompok ini memiliki berbagai macam tipe, namun yang ingin diterapkan dalam penelitian ini adalah tipe Team Accelerated 
Intrucsion (TAI) yang dapat digunakan untuk meningkatkan dan mengefektifkan implementasi kurikulum 2004. Kooperatif dalam matematika juga akan dapat membantu para siswa meningkatkan sikap positif siswa dalam metematika sehingga para siswa secara individu membangun kepercayaan diri terhadap kemampuannya, untuk menghilangkan rasa cemas terhadap matematika (math a xietiy), yang banyak dialami para siswa. dengan menonjolkan interaksi dalam kelompok. Model belajar kooperatif learning tipe Team Asccelerated Intriction (TAI) dapat membuat siswa menerima siswa lain yang berkemampuan dan berlatar belakang yang berbeda. Metode ini juga telah terbukti dapat meningkatkan berfikir kritis serta meningkatkan kemampuan siswa dalam pemecahan masalah. Untuk menjamin heterogenitas keanggotaan kelompok, maka gurulah yang membentuk kelompok-kelompok tersebut. Jika siswa dibebaskan membuat kelompok sendiri maka biasanya siswa akan memilih teman-teman yang sangat disukainya. Ukuran besar kecilnya kelompok akan mempengaruhi kemampuan produktivitas kelompoknya. Ukuran kelompok ideal pada tipe TAI ini adalah 3 sampai 5 orang.

Dengan menggunakan metode Kooperatif Learning tipe Team Accelerated Intruction (TAI) ini, diharapkan dalam proses pembelajaran siswa tidak merasa jenuh dan diharapkan dapat meningkatkan prestasi siswa. Prestasi belajar juga dapat dicapai dengan perjuangan yang tidak mengenal lelah dan putus asa yang sesuai dengan ungkapan "tidak ada sesuatu yang dapat dicapai tanpa kerja keras". Sebelumnya, sudah banyak penelitian yang telah dilakukan untuk menguji keefektifan dari penerapan kooperatif learning tipe Team Accelerated Intrucsion (TAI) dalam pembelajaran matematika di sekolah-sekolah. Namun masih sedikitnya yang menguji tentang ada tidaknya pengaruh kooperatif learning tipe Team akan dilakukan untuk dapat menguji sejauh mana "Upaya meningkatkan hasil belajar matematika melalui pendekatan kooperatif tipe Team Accelerated Intruction (TAI) terhadap prestasi belajar matematika SMK kelas XI SMK YASPIH RAJEG".

\section{METODE}

Jenis penelitian ini termasuk penelitian eksperimen. Metode yang digunakan adalah metode penelitian tindakan kelas (PTK) yang memerlukan beberapa siklus dan membutuhkan pembelajaran yang efektif. PTK ini dilaksanakan melalui tiga siklus untuk melihat hasil belajar matematika dengan digunakannya pembeljaran kooperatif. Dalam Penelitian Tindakan Kelas ini yang menjadi subjek penelititan adalah siswa kelas 10 AP SMK Yaspih Rajeg semester ganjil tahun ajaran 2012/2013 dengan jumlah siswa 34, orang yang terdiri dari 30 siswa perempuan dan 4 siswa laki - laki.

Pada tahap pelaksanaan pembelajaran, guru bersama - sama dengan kolaborator mementau saat kegiatan pembelajaran berlangsung. Selain itu guru/peneliti juga diamati dalam pembelajaran yang dilakukan oleh kolaborator. Pengamatan terhadap guru misalnya guru sebagai perencana, kolaborator, dan evaluator dalam pembelajaran dengan menggunakan metode pembelajaran kooperatif sebagai media untuk meningkatkan hasil belajar matematika siswa dalam menyelesaikan soal tentang sistem persamaa dan pertidaksamaan linier dan kuadrat.

Prosedur pengumpulan data dilakukan dengan cara memberikan tes kepada sumber data, melakukan observasi dan mencatat kejadian-kejadian di lapangan, dan memberikan angket kepada sumber data. 


\section{HASIL}

Tabel 1. Hasil Tes Evaluasi Siklus I

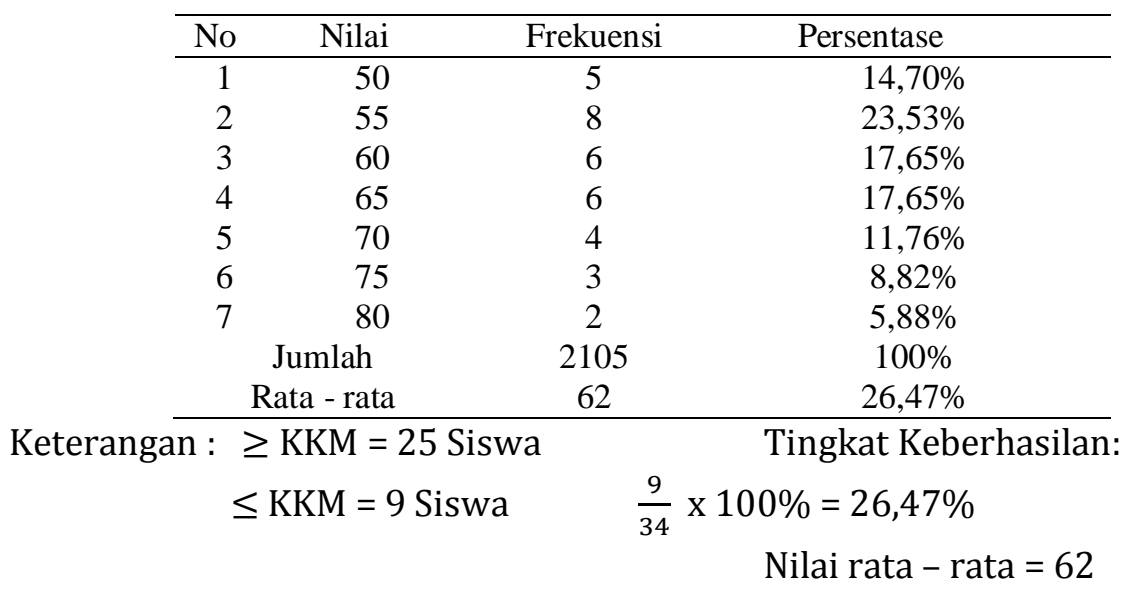

Berdasarkan hasil observasi/pengamatan kolaborator bahwa keberhasilan dan kegagalan yang terjadi pada siklus I sebagai berikut:

1) Kebanyakan siswa masih bingung apa yang harus dilakukan karena guru menyampaikan materi (bahan ajar) hanya bagian pokoknya saja sedangkan mereka sudah terbiasa mendapatkan penjelasan guru secara lengkap (detail)

2) Sebagian siswa belum terbiasa digabungkan dengan kelompok yang beda pergaulan, jenis kelamin dan tempat tinggal

3) Pada saat belajar berkelompok, siswa yang lebih pintar masih mendominasi dalam menyelesaikan soal - soal yang dianggap mereka sulit, sedangkan siswa yang lainnya mengobrol dan cuek, karena mereka belum faham aturan - aturan dalam belajar kelompok dan kerja sama

4) Sebagian besar jawaban siswa dalam mengerjakan soal - soal individu benar

5) Siswa masih kaku dalam mendiskusikan jawaban yang berbeda hasil kerja individu mereka didalam kerja kelompok

6) Siswa masih masih berusaha mencontoh atau menyalin hasil temannya yang lebih pintar walaupun belum tentu jawaban itu benar

7) Sebagian siswa belum terbiasa dengan kondisi dengan menggunakan metode pembelajaran kooperatif. hal ini bisa dilihat dari hasil observasi terhadap aktivitas siswa dalam proses pembelajaran hanya mencapai skor rata - rata 2,54

8) Hasil evaluasi siklus pertama mencapai rata - rata 62 dengan tingkat ketuntasan baru mencapai $26,47 \%$

9) Masih ada kelompok yang belum terbiasa meyelesaikan tugas dengan waktu yang ditentukan. Hal ini karena anggota kelompok tersebut kurang serius dalam belajar

Untuk memperbaiki kelemahan dan mempertahankan keberhasilan yang telah dicapai ada siklus pertama, maka pada pelaksanaan siklus I dapat dilakukan perencanaan sebagai berikut:

1) Memberikan motivasi kepada kelompok yang mengalami kesulitan

2) Lebih intensif membimbing kelompok yang mengalami kesulitan 
Memberikan pengakuan dan penghargaan (reward)

Tabel 2. Hasil Tes Evaluasi Siklus II

\begin{tabular}{cccc}
\hline No & Nilai & Frekuensi & Presentase \\
\hline 1 & 45 & 1 & $2,94 \%$ \\
2 & 50 & 1 & $2,94 \%$ \\
3 & 55 & 4 & $11,76 \%$ \\
4 & 60 & 3 & $8,82 \%$ \\
5 & 65 & 7 & $20,59 \%$ \\
6 & 70 & 12 & $35,29 \%$ \\
7 & 75 & 4 & $11,76 \%$ \\
8 & 80 & 2 & $5,88 \%$ \\
\multicolumn{2}{c}{ Jumlah } & 2250 & $100 \%$ \\
Rata - rata & 66,17 & $52,95 \%$ \\
\hline
\end{tabular}

Keterangan : $\geq \mathrm{KKM}=16$ Siswa

Tingkat Keberhasilan:

$\leq \mathrm{KKM}=18$ Siswa

$\frac{18}{34} \times 100 \%=52,95 \%$

Nilai rata - rata $=66,17$

Berdasarkan hasil observasi / pengamatan yang kolaborator lakukan bahwa keberhasilan pada siklus II sebagai berikut:

1) Siswa mulai mampu beradaptasi dan membangun kerjasama serta memahami tugas yang diberikan oleh guru, sehingga mampu berpartsipasi dalam kegiatan dan tepat waktu dalam melaksanakannya

2) Siswa mulai aktif dan mengikuti kegiatan belajar mengajar dengan baik, hal ini dapat dilihat dari data observasi terhadap aktivitas siswa meningkat dari skor rata - rata sebesar 2,54 pada siklus I menjadi 3,36pada siklus II

3) Pada waktu belajar kelompok, sebagian siswa berani mengemukakan pendapat, meskipun masih ada beberapa yang ngobrol

4) Sebagian siswa pada waktu mengerjakan tugas indivudu sudah timbul kepercayaan diri dan tidak merasa cemas, takut salah, meskipun sesekali melihat pekerjaan teman.

5) Siswa yang lebih pintar sudah tidak mendominasi dalam menyelesaikan soal - soal pada waktu belajar kelompok sesekali memberikan peluang kepada yang lain

6) Meningkatkanya aktivitas siswa dalam proses pembelajaran didukung oleh menigkatnya aktivitas guru dalam mempertahankan dan meningkatkan suasana pembelajaran dengan menggunakan metode pembelajaran kooperatif. Guru intensif membimbing siswa dalam mengalami kesulitan dalam proses pembelajaran, hal ini dilihat dari hasil observasi aktivitas guru, proses pembelajaran meningkat dari skor rata - rata 2,54 pada siklus I menjadi 4 pada siklus II

7) Meningkatnya aktivitas siswa dalam melaksanakan evaluasi terhadap kemampuan siwa menguasai materi pembelajaran. Hal ini dapat dilihat dari hasil evaluasi dengan tingkat ketuntasan pada siklus I : $26,47 \%$ (rata - rata $=62$ ) pada siklus II menjadi 52, 95\% (rata - rata $=66,17)$. 
Tabel 3. Hasil Tes Evaluasi Siklus III

\begin{tabular}{cccc}
\hline No & Nilai & Frekuensi & Persentase \\
\hline 1 & 55 & 3 & $8,83 \%$ \\
2 & 60 & 1 & $2,94 \%$ \\
3 & 65 & 6 & $14,31 \%$ \\
4 & 70 & 9 & $26,47 \%$ \\
5 & 75 & 14 & $44,12 \%$ \\
6 & 80 & 1 & $2,94 \%$ \\
\multicolumn{2}{c}{ Jumlah } & 2724 & $100 \%$ \\
\multicolumn{2}{c}{ Rata - rata } & 80,13 & $91,17 \%$ \\
\hline
\end{tabular}

Keterangan : $\geq \mathrm{KKM}=31$ Siswa

Tingkat Keberhasilan:

$\leq \mathrm{KKM}=3$ Siswa

$\frac{31}{34} \times 100 \%=91,17 \%$

Nilai rata - rata $=80,13$

Berdasakan hasil observasi/pengamatan yang kolaborator lakukan bahwa keberhasilan pada siklus III sebagai berikut:

a. Siswa mampu membangun kerjasama dan memahami tugas yang diberikan oleh guru

b. Pada saat kagiatan berkelompok, sebagian besar siswa sudah berani menyampaikan pendapat mereka masing - masing dan siswa yang lebih pintar tidak mendominasi

c. Pada saat mengerjakan soal tugas individu sudah tertanam rasa percaya diri, tidak cemas, tidak kaku, meskipun siswa ada siswa yang bertanya

d. Sebagian besar jawaban siswa dalam mengerjakan soal - soal individu banyak yang benar

e. Antara anggota kelompok terjadi saling membimbing dan membantu dalam usaha menyelesaikan soal - soal

f. Setiap anggota kelompok bersikap demokratis dan berusaha untuk mencapai consnsus pendapat melalui argumentasi siswa mulai aktif dan mengikuti

g. Siswa mulai aktif dan mengikuti kegiatan belajar mengajar dengan baik, hal ini dapat dilihat dari data observasi terhadap aktivitas siswa meningkat skor rata - rata sebesar 2,54 pada siklus I menjadi 3,36 pada siklus II dan meningkat menjadi 4, 34 pada siklus III

h. Meningkatnya aktivitas siswa dalam proses pembelajaran didukung oleh meningkatnya aktivitas guru dalam mempertahankan dan meningkatkan suasana pembelajaran dengan menggunakan metode pembelajaran kooperatif. Guru intensif membimbing siswa dalam mengalami kesulitan dalam proses pembelajaran, hal ini dapat dilihat dari hasil observasi aktivitas guru, proses pembelajaran meningkat dari skor rata - rata 2,5 pada siklus I menjadi 4 pada siklus II dan 4,5 pada siklus III

i. Meningkatnya aktivitas siswa dalam melaksanakan evaluasi terhadap kemampuan siswa menguasai materi pembelajaran. Hal ini dapat dilihat dari hasil evaluasi dengan tingkat ketuntasan $26,47 \%$ ( rata rata $=62$ ) pada siklus I menjadi 52,95\% (rata - rata $=66,17)$ dan menjadi $91,18 \%($ rata - rata $=80,14)$ pada siklus III. 
Berdasarkan hasil observasi kolaborator terhadap siswa saat pembelajaran pada siklus I, II, dan III berlangsung, dapat penulis buat rekapitulasi sebagai berikut:

Tabel 4..Rekapitulasi Hasil Observasi Terhadap Aktivitas Siswa Pada Siklus I, II dan III

\begin{tabular}{ccc}
\hline \multicolumn{3}{c}{ Rata - rata Skor } \\
\hline Siklus I & Siklus II & Siklus III \\
2,54 & 3,36 & 4,34 \\
\hline
\end{tabular}

Dari tabel tersebut dapat digambarkan dalam bentuk grafik sebagai berikut:

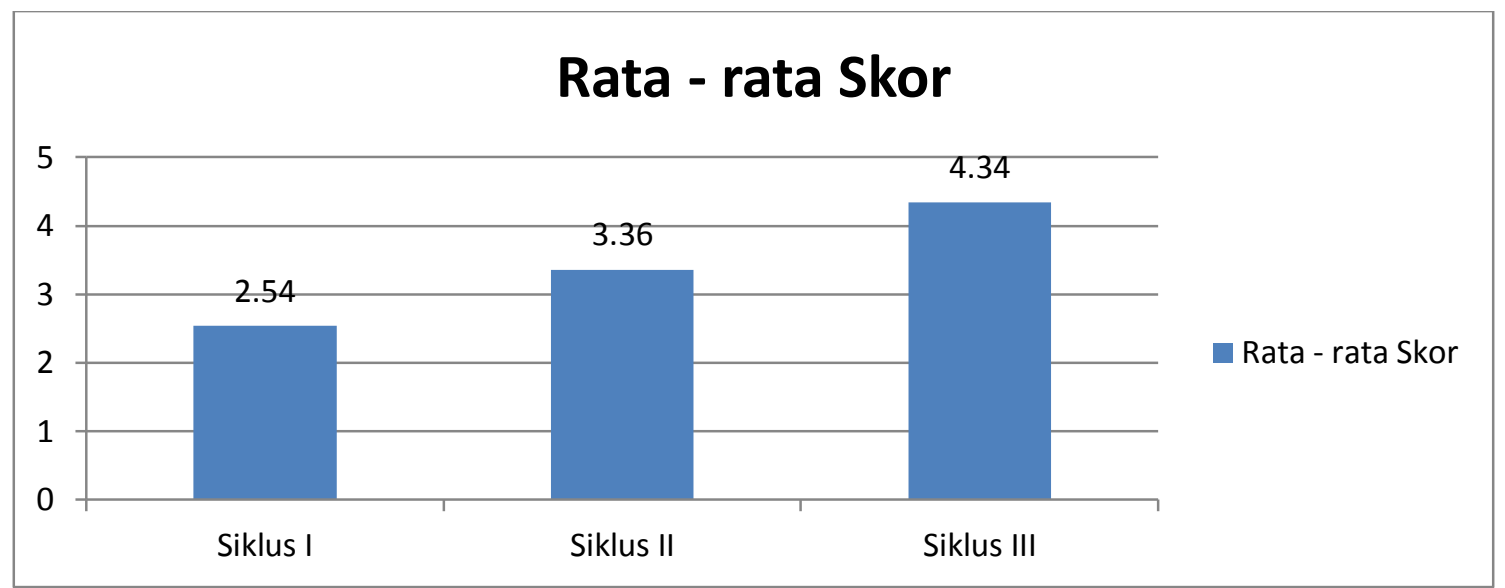

Gambar 1. Grafik Rekapitulasi Hasil Observasi Terhadap Guru Siklus I, II, dan III

Berdasarkan tabel dan grafik diatas tentang hasil observasi terhadap siswa diketahui bahwa rata rata skor yang diperoleh pada siklus I sebesar 2,54, pada siklus II mengalami peningkatan menjadi 3,36 dan pada siklus III meningkat menjadi 4,34 . Hal ini berarti bahwa dengan digunakannya metode pembelajaran kooperatif dalam pembelajaran, keaktifan siswa mengalami peningkatan dari siklus I hingga siklus III. Dengan meningkatnya keaktifan siswa, maka akan berdampak positif terhadap peningkatan hasil belajar siswa.

Berdasarkan hasil observasi yang kolaborator lakukan terhadap guru pada siklus I, II, dan III berlangsung dapat dibuatkan rekapitulasi akhir sebagai berikut:

Tabel 5. Rekapitulasi Hasil Observasi terhadap Aktivitas Guru pada Siklus I, II, dan III

\begin{tabular}{ccc}
\hline \multicolumn{3}{c}{ Rata - rata Skor } \\
\hline Siklus I & Siklus II & Siklus III \\
2,5 & 4 & 4,5 \\
\hline
\end{tabular}

Dari tabel diatas, dapat digambarkan dalam bentuk grafik sebagai berikut: 




Gambar 2. Grafik Rekapitulasi Hasil Observasi terhadap Guru Siklus I, II, dan III

Berdasarkan tabel dan grafik diatas tentang hasil observasi terhadap guru diketahui bahwa rata - rata skor yang diperoleh pada siklus I sebesar 2,5, pada siklus II mengalami peningkatan menjadi 4 dan pada siklus III meningkat menjadi 4,5. Hal ini berarti bahwa guru telah melakukan perbaikan dalam kegiatan belajar mengajar dari siklus I, II hingga siklus III khususnya penerapan metode pembelajaran kooperatif. Dengan diterapkannya metode pembelajaran kooperatif dalam kegiatan pembelajaran, menjadi lebih cepat memahami materi yang sedang dibahas, yang pada akhirnya akan berdampak positif terhadap peningkatan hasil belajar siswa.

Berdasarkan hasil evaluasi terhadap keberhasilan pembelajaran pada siklua I, II, dan siklus III dapat dibuatkan rekapitulasi sebagai berikut:

Tabel 6. Rekapitulasi Hasil Tes Evaluasi Siklus I ,II, dan III

\begin{tabular}{|c|c|c|c|c|}
\hline \multirow{2}{*}{ No } & \multirow{2}{*}{ Nilai } & \multicolumn{3}{|c|}{ Frekuensi } \\
\hline & & Siklus I & Siklus II & Siklus IIII \\
\hline 1 & 40 & - & - & - \\
\hline 2 & 45 & - & 1 & - \\
\hline 3 & 50 & 5 & 1 & - \\
\hline 4 & 55 & 8 & 4 & 3 \\
\hline 5 & 60 & 6 & 3 & 1 \\
\hline 6 & 65 & 6 & 7 & 5 \\
\hline 7 & 70 & 4 & 12 & 9 \\
\hline 8 & 75 & 3 & 4 & 15 \\
\hline 9 & 80 & 2 & 2 & 1 \\
\hline 10 & 85 & - & - & - \\
\hline 11 & 90 & - & - & - \\
\hline \multicolumn{2}{|c|}{ Jumlah } & 2105 & 2250 & 2725 \\
\hline \multicolumn{2}{|c|}{ Rata - rata } & 62 & 66,17 & 80,13 \\
\hline
\end{tabular}

Dari tabel diatas dapat digambarkan dalam bentuk grafik sebagai berikut: 


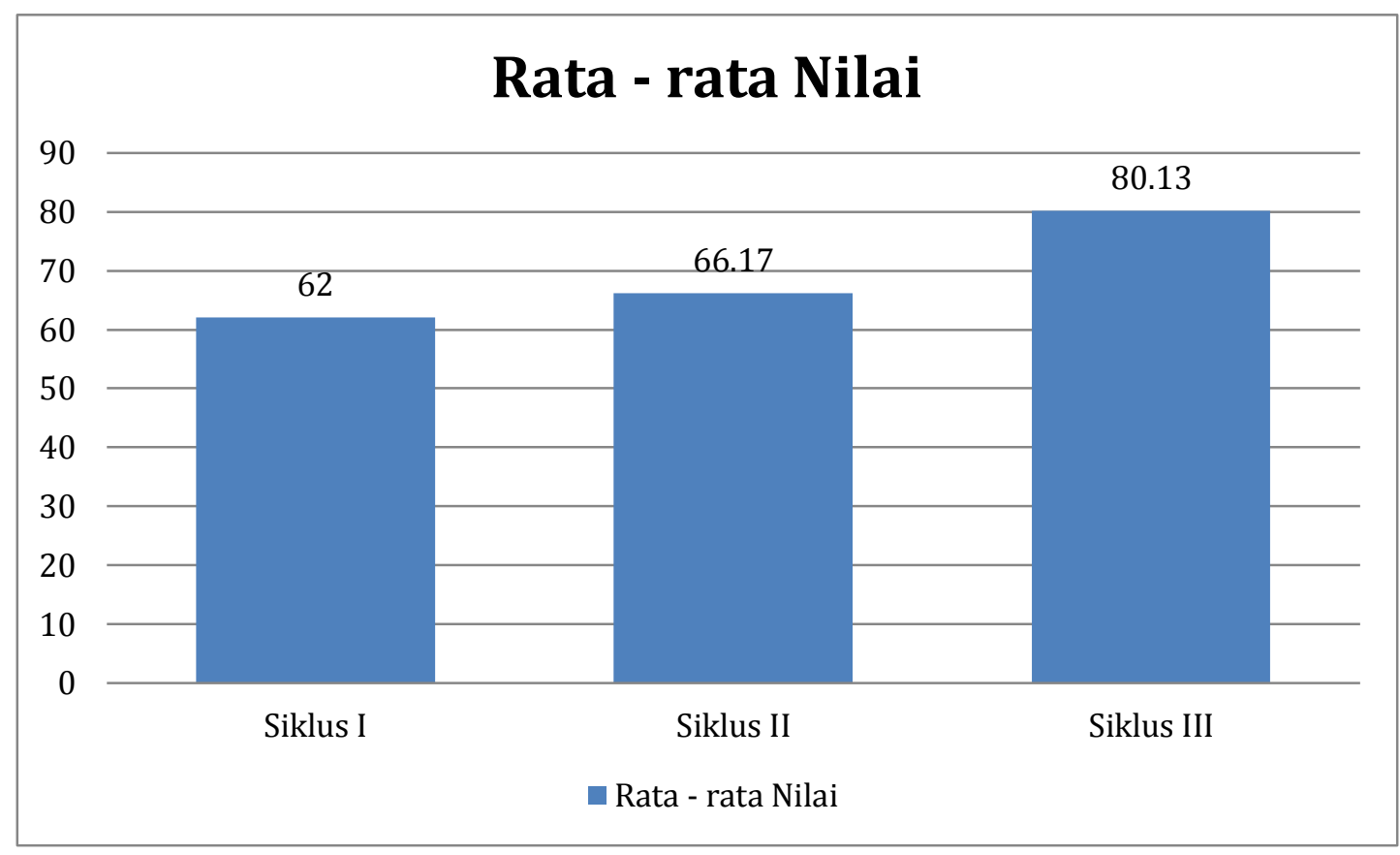

Gambar 3. Grafik Rekapitulasi Nilai Rata- rata Siswa Siklus I, II dan III

Tabel 7. Rekapitulasi Hasil Ketuntasan Belajar Pada Siklus I, II, dan III

\begin{tabular}{ccc}
\hline Siklus I & Siklus II & Siklus III \\
\hline $26,47 \%(9$ siswa $)$ & $52,95 \%(18$ siswa $)$ & $91,18 \%(31$ siswa $)$ \\
\hline
\end{tabular}

Dari tabel di atas dapat digambarkan dalam bentuk grafik sebagai berikut



Gambar 4. Grafik Rekapitulasi Persentase Ketuntasan Siswa Siklus I, II, dan III

Berdasarkan tabel dan grafik diatas dapat diketahui bahwa adanya peningkatan rata - rata hasi tes evaluasi pada siklus I hanya mencapai 62 denagan tingkat ketuntasan 26,47\% (9 siswa) meningkat menjadi 
66,17 dengan tingkat ketuntasan 52,95\% (18 siswa) pada siklus II dan pada siklus III menjadi 80,14 dengan tingkat ketuntasan 91,18\% (31 siswa). Hal ini menunjukkan bahwa metode pembelajaran kooperatif cukup efektif dalam meningkatkan hasil belajar siswa khususnya mata pelajaran matematika siswa kelas 10 AP SMK YASPIH RAJEG.

\section{PEMBAHASAN}

Berdasarkan data yang diperolehkolaborator bahwa penggunaan metode pembelajaran kooperatif dapat meningkatkan hasil belajar siswa. Hal ini dapat terlihat dari keaktifan siswa dalam proses pembelajaran. Terlihat dari hasil pengamatan/observasi terhadap siswa didapatkan rata - rata skor pada siklus I $=2,54$, siklus II $=3,36$, dan siklus III $=4,34$. Peningkatan tersebut dikernakan guru telah melakukan perbaikan pembelajaran sesuai dengan refleksi tiap siklus mulai dari siklus I sampai dengan siklus III dengan perolehan rata - rata skor pada siklus I = 2,5 siklus II $=4$ dan siklus III $=4,5$. Hasi belajar matematika siswa mengalami peningkatan. Hal ini dapat ditunjukan dengan hasil evaluasi tiap siklus yaitu pada nilai rata rata nilai siswa pada siklus $\mathrm{I}=62$ siklus $\mathrm{II}=66,17$ dan siklus $\mathrm{III}=80,14$. Sedangkan tingkat ketuntasan siswa juga mengalami peningkatan yaitu pada siklus I = 26, $47 \%$ (9 siswa), siklus II 52, $95 \%$ (18 siswa) dan siklus III $=86,67 \%$ (31 siswa).

Berdasarkan hasil wawancara dan angket menunjukan bahwa antusiasisme siswa terhadap pembelajaran mengalami peningkatan hal ini terlihat dari rekapitulasi angket dan wawancara siswa, sebagian siswa pada siklus I menyatakan bahwa pembelajaran yang dilakukan tidak terlalu berpangaruh, artinya tidak ada hasil signifikan yang terjadi. Tetapi pada siklus II menunjukan bahwa antusiasisme siswa meningkat begitupun dengan siklus III, peningkatan antusiasisme belajar dan perubahan yang terjadi dalam pembelajaran berpengaruh terhadap hasil evaluasi siswa, terjadi peningkatan yang cukup signifikan

Terdapat keterkaitan antara instrumen - instrumen pengamatan /observasi tersebut, dengan peningkatan hasil belajar siswa dimana peningkatan aktivitas belajar dan antusiasisme siswa dan guru berbanding lurus dengan peningkatan hasil belajar siswa yang kemudian dapat penulis simpulkan bahwa metode pembelajaran kooperatif cukup efektif dalam meningkatkan hhasil belajar siswa.

Metode pembelajaran kooperatif pada pokok bahasan persamaan dan pertidaksamaan siswa kelas 10 AP SMK YASPIH RAJEG sesuai karena dengan latar belakang sosial yang beragam,dengan perpaduan belajar individual dan kelompok, metode pembelajaran kooperatif dapat menekankan kepada keaktifan siswa dalam upaya meningkatkan hasil belajar, karena siswa langsung mengerjakan banyak latihan soal dan mencari penyelesaiannya secara berkelompok didukung oleh keaktifan dan bimbingan guru terhadap siswa, menggunakan alat pembelajaran yang relevan, untuk membangkitkan minat belajar siswa serta pengorganisasian materi pembelajaran dilakukan secara cermat dengan menggunakan prinsip belajar dan mengajar. 


\section{SIMPULAN}

Berdasarkan hasil wawancara dan angket menunjukan bahwa antusiasisme siswa terhadap pembelajaran mengalami peningkatan hal ini terlihat dari rekapitulasi angket dan wawancara siswa, sebagian siswa pada siklus I menyatakan bahwa pembelajaran yang dilakukan tidak terlalu berpangaruh, artinya tidak ada hasil signifikan yang terjadi. Tetapi pada siklus II menunjukan bahwa antusiasisme siswa meningkat begitupun dengan siklus III, peningkatan antusiasisme belajar dan perubahan yang terjadi dalam pembelajaran berpengaruh terhadap hasil evaluasi siswa, terjadi peningkatan yang cukup signifikan. Sehingga. dapat penulis simpulkan bahwa metode pembelajaran kooperatif cukup efektif dalam meningkatkan hhasil belajar siswa.

\section{DAFTAR RUJUKAN}

Hasbullah. (2005). Dasar Ilmu Pendidikan. Jakarta. Penerbit: PT Raja Grasindo Persada

Sukmadinata, Nana Syaodih. (2004). Landasan Psikologi Proses Pendidikan. Bandung: PT remaja Rosdakarya.

Karim, Abdul. 2017. Pengaruh Metode Mencongak terhadap Hasil Belajar Matematika. JKPM Vol. 2 No. 2 Juni 2017 